\title{
Lament for Syria
}

\author{
Amineh Abou Kerech ${ }^{1}$ \\ Syria / United Kingdom
}

[Article copies available for a fee from The Transformative Studies Institute. E-mail address: iournal@transformativestudies.org Website: http://www.transformativestudies.org (02020 by The Transformative Studies Institute. All rights reserved.]

Syrian doves croon above my head their call cries in my eyes.

I'm trying to design a country that will go with my poetry and not get in the way when I'm thinking, where soldiers don't walk over my face.

I'm trying to design a country which will be worthy of me if I'm ever a poet and make allowances if I burst into tears. I'm trying to design a City of Love, Peace, Concord and Virtue, free of mess, war, wreckage and misery.

Oh Syria, my love

I hear your moaning in the cries of the doves. I hear your screaming cry. I left your land and merciful soil And your fragrance of jasmine My wing is broken like your wing.

\footnotetext{
${ }^{1}$ Amineh Abou Kerech lived in a suburb of Damascus when the Syrian conflict began, forcing her family to leave Syria in 2012 when she was eight years old. After four years in Egypt, the family settled in Oxford, England, and Amineh began the adjustment to a new country and a new language. After only one year of learning English, she wrote "Lament for Syria" and won the Betjeman poetry prize. Poem printed with permission.
} 
I am from Syria

From a land where people pick up a discarded piece of bread

So that it does not get trampled on

From a place where a mother teaches her son not to step on an ant at the end of the day.

From a place where a teenager hides his cigarette from his old brother out of respect.

From a place where old ladies would water jasmine trees at dawn.

From the neighbours' coffee in the morning

From: after you, aunt; as you wish, uncle; with pleasure, sister...

From a place which endured, which waited, which is still waiting for relief.

Syria.

I will not write poetry for anyone else.

Can anyone teach me

how to make a homeland?

Heartfelt thanks if you can,

heartiest thanks,

from the house-sparrows,

the apple-trees of Syria,

and yours very sincerely.

"Poems sometimes give us a lot of emotionally meaning or sometimes it could show the writer's situation. Letters, papers and pens were the most closer friends to me, when I went through a keen pain period from what my eyes have seen. The time I've been through, my body was heavy of letters which lost their own place, where it started to go around and breathed those letters and throw these destroyed words into the paper." - Amineh Abou Kerech 